\title{
FINANCE, BANKING AND INSURANCE
}

\section{RECEIVED: \\ 18 January 2021 \\ ACCEPTED: \\ 18 February 2021 \\ RELEASED: \\ 20 March 2021}

UDC 657.2:336.7

DOI 10.26661/2522-1566/2021-1/15-01

\section{TRANSFORMATION OF CASHLESS PAYMENTS IN THE EUROPEAN PAYMENT CARD MARKET}

\author{
Kyrylo Arabadzhy \\ Borys Grinchenko \\ University of Kyiv \\ Kyiv, Ukraine \\ ORCID: 0000-0002-7535-6824
}

\author{
Valeriia Zharnikova \\ Kyiv National University \\ of Trade and Economics \\ Kyiv, Ukraine \\ ORCID: 0000-0002-4335-5149
}

\author{
Olena Sobolieva-Tereshchenko* \\ Borys Grinchenko \\ University of Kyiv \\ Kyiv, Ukraine \\ ORCID: 0000-0002-1086-1192
}

*Corresponding author email: o.tereshchenko@kubg.edu.ua

\begin{abstract}
The purpose of this study is to examine the current state and perspectives of noncash payments by using payment cards in Ukraine, Poland, Sweden, Romania and Hungary. The factors of transformation of the term "non-cash payments" into the term "payment system" are considered in the article. Methodology: The theoretical and practical database of the bank cards market is considered as an information base of the research. In the course of the research general, scientific, theoretical and empirical methods were used, among which are the following: analysis and generalization of literature on the research topic, methods of observation and comparison, structural methods, methods of coordination and formalization, graphical and tabular representation of data. The article presents trends in the development of new types of non-cash money, compares the development of the payment card market on a number of criteria and describes the main directions of modern use of payment cards for non-cash payments in the analyzed countries. The European Central Bank (ECB) data set, information from sites National Bank of Ukraine and Central banks of countries were collected for comparative economic research. The research findings show that changes of bank cards market greatly influence the development of non-cash payment in economy. The research findings show that changes in bank cards market greatly influence the development of non-cash payment in economy. The scientific significance of the work is that in article the issue of the factors of transformation of the non-cash settlement system into a payment system. The practical significance of the results is that in article shows in detail the ways to improve the Ukrainian market of bank cards using the experience of other EU countries. This article offers insights on the best European practice and challenges of on the bank cards market during 2015 2019 years.
\end{abstract}

Keywords: non-cash (cashless) settlements, bank, payment cards, POS-terminal, Ukraine, Poland, Sweden, Romania, Hungary.

JEL Classification: G15, G21, O12. 
Arabadzhy, K., Zharnikova, V. \& Sobolieva-Tereshchenko, O. (2021), “Transformation of cashless payments in the European payment card market”, Management and entrepreneurship: trends of development, 1(15), pp.8-23. Available at: https://doi.org/10.26661/2522-1566/2021-1/15-01

\section{INTRODUCTION}

Non-cash payments are important in the financial and economic environment of each country and are the basis for building a global non-cash economy. It allows not only to reduce cash flow, but also to accelerate commercial interaction between agents of economic activity, reduce the level of shadow economy, encourage the development of e-commerce and online technologies and ensure the introduction of new types of financial services. Proliferation of non-cash payments using payment cards is one of the most pressing issues in the development of the global system of noncash payments and the development of the banking system in general.

During the study of the fettle of non-cash payments using payment cards was conducted the analysis of five European countries. To substantiate the theoretical provisions and independent researches was processed the scientific researches and articles by practitioners, structed the statistical information of the ECB and European Banking Federation (EBF), also it was used the methods of synthesis and comparative analysis, concise and formalized presentation of basic information were used as well.

The aim of the study is to compare the level of the using of non-cash payments in such countries as: Ukraine, Poland, Sweden, Romania, Hungary, in the field of acquiring, and non-cash payments. Firstly, these countries were chosen for comparison with Ukraine, based on the fact that Poland, Romania and Hungary are neighboring countries with which it would be appropriate to equate Ukrainian opportunities. Secondly, the comparison of Ukraine with such developed European country as Sweden was chosen to show the dynamics between the indicators and to identify the existing problems and opportunities for Ukraine's development by the method of comparison.

The scientific importance of the work is that on the basis of the conducted research the specification of the terms "non-cash payments" and "payment system", which are related to the banking system in the field of acquiring and typical banking operations, was made. Of particular importance is the study of the impact of the development of new technologies, best practices in the transition to non-cash payments on digital currency in individual countries under study. Also, the directions of stimulating non-cash payments and accelerating payments and transfers of funds between banks, customers and accounts for Ukraine based on the experience of European countries are outlined.

\section{LITERATURE REVIEW}

Over the past five years, non-cash payments and banking have changed substantially in organizational and technological ways, also its role of the economy has changed significantly. Besides, the perception of non-cash payments and payment systems has changed. It is a problem between mutual understanding of clear conceptual representation of non-cash payments.

Many scientists and economists have studied non-cash payments, including I. Novak and L. Goncharenko (2010), V. Kravets (2016), V. Kharchenko and R. Kapralov (2010), and others. At the same time, the tendency to update the essence of non-cash payments, their modernization in the digital economy determines the relevance of this issue today. Elaboration of scientific works of various economists on non-cash money and non-cash payments allowed us to conclude that the definition of "non-cash" does not involve the use of cash, and the term "calculations" characterizes the process of calculating monetary obligations.

The concept of "payment system" studied in such works: Ya. Chaikovskii and Ya. Kovalchuk (2018), S. Zorya (2017), N. Rushchyshyn and Z. Kostak (2018), H. Treiblmaier and A. Floh (2006). As a result of processing their works, it was found that the authors have different approaches to the disclosure of the meaning of the "payment system" and, accordingly, there is terminological confusion due to unconventional interpretations of this concept. 
Since 2015, the banking card business has changed significantly in both technological and organizational terms. The banking sector is developing rapidly under the influence of new technologies. The introduction of new technologies allows to make innovative breakthroughs in the banking sector, in particular in the field of cashless payments.

The works of both individual researchers and financial organizations are devoted to the digital transformation. Among the relevant studies are the works of O. Selcen et al. (2019), M. Massimo et al. (2020), J. Cronk (2015), B. King (2017), V. Zharnikova (2019) les by Global Finance, The Economic Times and Zacks, and World Bank reports. Many domestic scholars, such as, in particular, E. Maslennikov et al. (2017), A. Ramskyi et al. (2017), O. SobolievaTereshchenko (2018), S. Reverchuk et al. (2015), O. Sobolieva-Tereshchenko and Y. Zhukova (2020), were engaged in researches of questions of essential organizational changes concerning Integration of Ukraine into the European banking system and institutional transformation. Thereby, it needs to study the market of payment cards in the analyzed countries on a number of criteria and identify trends in the use of payment cards for cashless payments.

\section{PAPER OBJECTIVE}

In the current conditions of world economic development, the digital transformation has covered all spheres of the economy, including banking. It provides new opportunities for banks to increase their competitiveness, increase the number of customers and profits. Also, the digital transformation of cashless payments has an impact on the population, business and economy of the country. For citizens, it is the use of convenient, secure and fast payment transactions that prevent the loss of funds. For businesses, it is the simplification of payment transactions, optimization of resource costs to work with cash proceeds, the prospect of conducting part of the business in remote channels. In general, for the country it is a simplified system of social benefits, the struggle against the shadow economy.

Expanding the scope of cashless payments contributes to the transparency of payments and economic growth of the country. The National Bank of Ukraine supports the movement of the country's economy to cashless payments and promotes the development of payment infrastructure. The spread of non-cash payments is being implemented in the framework of the implementation of the Concept of development of the digital economy of Ukraine in 2018-2020 and the Concept of reforming the payment legislation of Ukraine.

The aim of the article is to identify similarities and differences in the use of non-cash payments and the use of payment systems in Ukraine, Poland, Switzerland, Hungary, Romania, to identify problems and methods to improve these issues in our country.

\section{METHODOLOGY}

The following research methods are used in the work: abstract-logical; statistical; comparative; of logical generalization; of economic and system analysis; of grouping; of critical analysis and theoretical research generalization.

\section{RESULT AND DISCUSSION}

The term "payment system" entered banking terminology in the late 1990s, and it essentially replaced the term "cashless payment system": that had previously been used. Therefore, in many modern books about money circulation or banking, the definition of "cashless payment system" is completely absent or is replaced by the term "payment system". Thus, today there is a need of studying the process of transformation of the term "cashless payments" to the term "payment system", as well as to clarify their terminology. 
Arabadzhy, K., Zharnikova, V. \& Sobolieva-Tereshchenko, O. (2021), “Transformation of cashless payments in the European payment card market”, Management and entrepreneurship: trends of development, 1(15), pp.8-23. Available at: https://doi.org/10.26661/2522-1566/2021-1/15-01

A comparison of the terms cashless payments and payment systems revealed some differences. First, the difference between these terms is that non-cash money is a record in bank accounts, and payment systems include technical mechanisms for conducting and accounting for these records. Secondly, the concept of payment system is broader and more complex, because it includes not only the object, - money, but also the procedures with this object, and the entities that implement these procedures.

A comparative analysis of the concepts and components of the "cashless payment system" and the "payment system" are presented in Table 1.

Table 1

Comparison of concepts of cashless payment systems and payment systems

\begin{tabular}{|c|c|c|}
\hline $\begin{array}{l}\text { Components of } \\
\text { the system }\end{array}$ & System of cashless payments & Payment systems \\
\hline Definition & $\begin{array}{l}\text { Method of payment for goods and } \\
\text { services. }\end{array}$ & $\begin{array}{l}\text { An innovative mechanism for transferring } \\
\text { funds between banks and institutional entities } \\
\text { for goods and services }\end{array}$ \\
\hline Subject & Commercial and central banks & $\begin{array}{l}\text { Commercial and central banks, specialized } \\
\text { companies, intermediaries, regular shops and } \\
\text { shopping centers }\end{array}$ \\
\hline $\begin{array}{l}\text { Form of } \\
\text { calculations }\end{array}$ & $\begin{array}{l}\text { Depends on the settlement document, } \\
\text { which carries a certain form of } \\
\text { calculation and no other }\end{array}$ & $\begin{array}{l}\text { Currently, all settlement documents are } \\
\text { presented with the usual details, which are } \\
\text { used on the basis of a payment order }\end{array}$ \\
\hline $\begin{array}{l}\text { Calculation } \\
\text { method }\end{array}$ & $\begin{array}{l}\text { The procedure of writing off and } \\
\text { accruing funds according to the } \\
\text { systems of all parties to the } \\
\text { calculation }\end{array}$ & $\begin{array}{l}\text { One-time transaction on customer accounts, } \\
\text { transfer of funds, which is very fast in terms } \\
\text { of the use of the latest technologies }\end{array}$ \\
\hline $\begin{array}{l}\text { Calculation } \\
\text { tools }\end{array}$ & $\begin{array}{c}\text { Transfer to participants of calculations } \\
\text { of certain documents of settlement } \\
\text { character which delay process of } \\
\text { payment }\end{array}$ & $\begin{array}{l}\text { Current account of the counterparty, or the } \\
\text { person in whose favor the transaction is to be } \\
\text { made }\end{array}$ \\
\hline Document flow & $\begin{array}{l}\text { The procedure of submitting all the } \\
\text { necessary documents is lengthy }\end{array}$ & $\begin{array}{l}\text { One file with documents, in the network of } \\
\text { Internet banking, mobile banking, blockchain } \\
\text { technologies }\end{array}$ \\
\hline
\end{tabular}

Source: Compiled by the authors according to (J. Cronk, 2015), (V. Zharnikova,2019), (O. Selcen et al., 2019).

It should be noted that the term "payment system" more fully reflects the system of using non-cash payments and electronic money in modern conditions of building a global non-cash economy. Respectively, in the scientific literature and research there is a tendency to replace the definition of "non-cash payment system" with "payment system". The transformation of the system of non-cash payments into a payment system took place under the influence of the following factors, which are shown in Figure 1. 


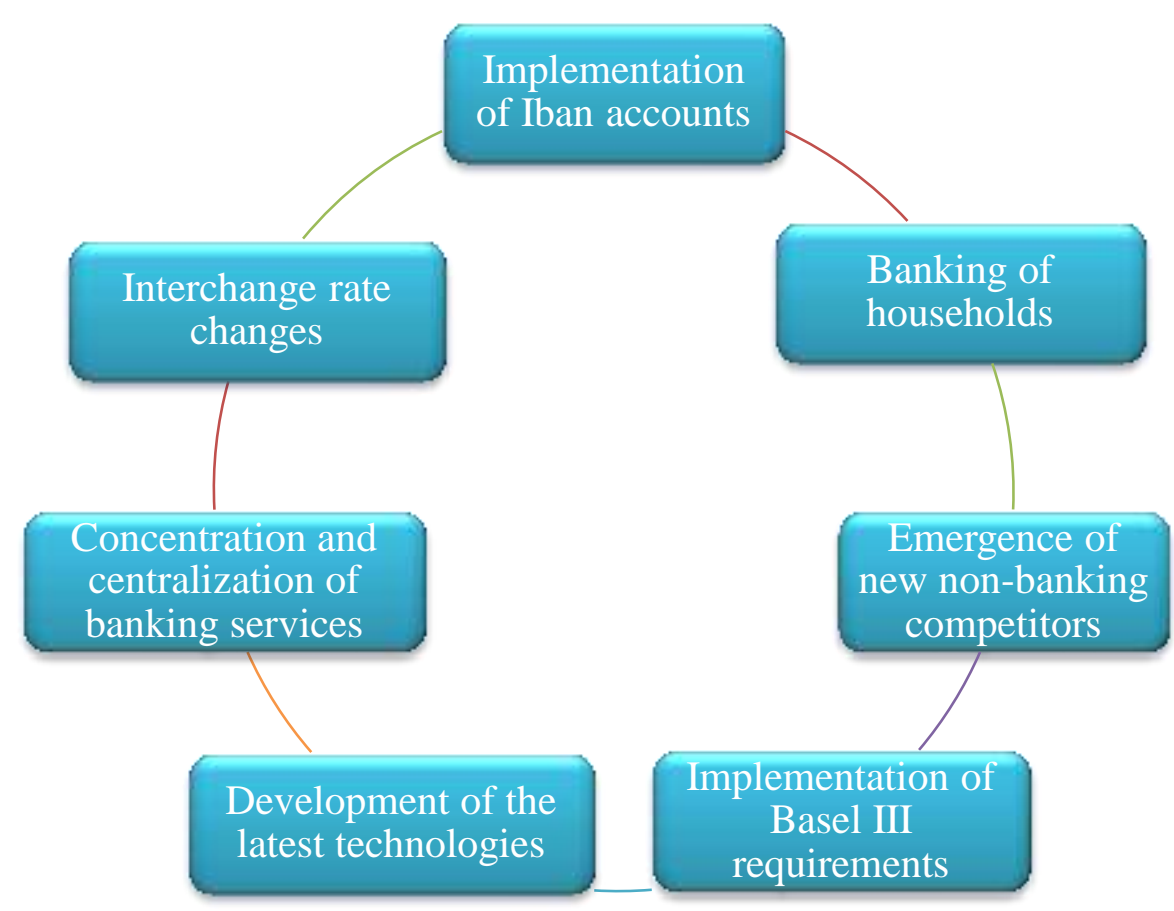

Figure 1. Factors a transformation of the system of non-cash payments into a payment system

\section{Source: Own study.}

Thus, the transformation of the non-cash payment system into a payment system was influenced by seven factors: banking of households, emergence of new non-banking competitors, development of new technologies, concentration and centralization of capital, changes in interchanging rates, implementation of Basel III requirements, introduction of IBAN accounts.

"Household banking" is a global phenomenon in the world economy and the economy of the EU. It is manifested in an increase in the share of retail banking in the banking sector of European countries the spread of retail banking is reflected in the increase in banking operations for individuals, small businesses, small and medium enterprises. This was due to the development of the payment card market and led to the transformation of the system of non-cash payments into a payment system.

The general pattern towards the active development of the non-banking financial sector in the form of financial companies and credit unions has helped reduce the role of banks in traditional banking markets and intensified competition between banking institutions and non-banking financial companies. The main competition arose in the field of card business, namely in the field of lending by payment cards and card-to-card transfers, which ultimately contributed to the transformation of the system of non-cash payments into a payment system.

Computerization and development of new technologies are also a very important factor in changes in payment systems and non-cash payments at the global level. Distribution of chip and virtual payment cards, development of remote customer service via Internet and mobile banking, the emergence of digital currencies, cryptocurrencies, e-wallets, which are trying to be implemented in leading European countries, as well as contactless payments using gadgets with NFC function through payment services Apple Pay, Google Pay, Garmin Pay have led to major changes in banking sphere. This factor led not only to the transformation of banking products, but also the transformation of the system of non-cash payments into a payment system. 
Arabadzhy, K., Zharnikova, V. \& Sobolieva-Tereshchenko, O. (2021), “Transformation of cashless payments in the European payment card market”, Management and entrepreneurship: trends of development, 1(15), pp.8-23. Available at: https://doi.org/10.26661/2522-1566/2021-1/15-01

The reduction of interchanging rates on cards of international payment systems is also a factor in the transformation of the system of cashless payments into a payment system. On the one hand, the reduction of card exchange rates affects the reduction of fees for the use of payment cards and promotes the growth of non-cash payments, which has been confirmed by the experience of Poland and Hungary which introduced changes to the level or manner of setting the interchange fee. On the other hand, lower interchange rates in Ukraine may lead to the destruction of the historical system of non-cash payments and payment systems due to the increase in the payback period of the bank's POS-terminals. Lowering the interchange rate can lead to lower bank profits. Payment system practitioners believe that as a result, many banks will withdraw their terminals from business (primarily small and medium-size) and it will provoke the growth of the shadow economy increase, as many transactions will pass by the box office.

A significant factor in the transformation of the cashless payment system into a payment system was the concentration and centralization of banking services, which affected the transition from one-time services to renewable banking products with the simultaneous introduction of loyalty systems by banks and retailers, from cashback to reward programs. It should be noted that the concentration and centralization of banking services for individuals, small businesses, small and medium enterprises have become possible due to the use of payment cards by banks as a means of identifying customers and the first major banking product. A striking example of such use of payment cards by banks is a universal bank card from Privatbank.

On February 1, 2014, SEPA (Single Euro Payments Area) was introduced throughout the European Union - the only European procedure for non-cash payment transactions. SEPA has replaced the national payment systems of $28 \mathrm{EU}$ member states. SEPA uses the IBAN to identify the bank and account number. IBAN - standard № 13616 of the International Organization for Standardization ISO and the European Committee for Banking Standards ECBS - international bank account number. The use of IBAN has become mandatory in Ukraine since January 13, 2020. The introduction of IBAN made it possible to harmonize the Ukrainian payment space with the European one, and also contributed to the further modernization of the electronic payment system of the National Bank of Ukraine. In general, the use of the IBAN standard made it easier to issue settlement documents, accelerated interbank payments, simplified receipt and automatic processing of payments from EU counterparties, made it easier to identify the payer and recipient of non-cash transfers, facilitated the transformation of non-cash payments into a payment system.

A detailed analysis of the factors transforming the system of non-cash payments into a payment system showed that five of the seven factors mentioned above, namely: banking of households, the emergence of new non-banking competitors, development of new technologies, concentration and centralization of capital, reduction of interchanging rates development of the payment card market.

Payments using payment cards are non-cash. The popularity of non-cash payments by payment cards is constantly growing, as evidenced by the growing number of transactions made with payment cards in Ukraine, Sweden, Poland, Hungary and Romania. Number of bank card payments in European countries on Figure 2. 


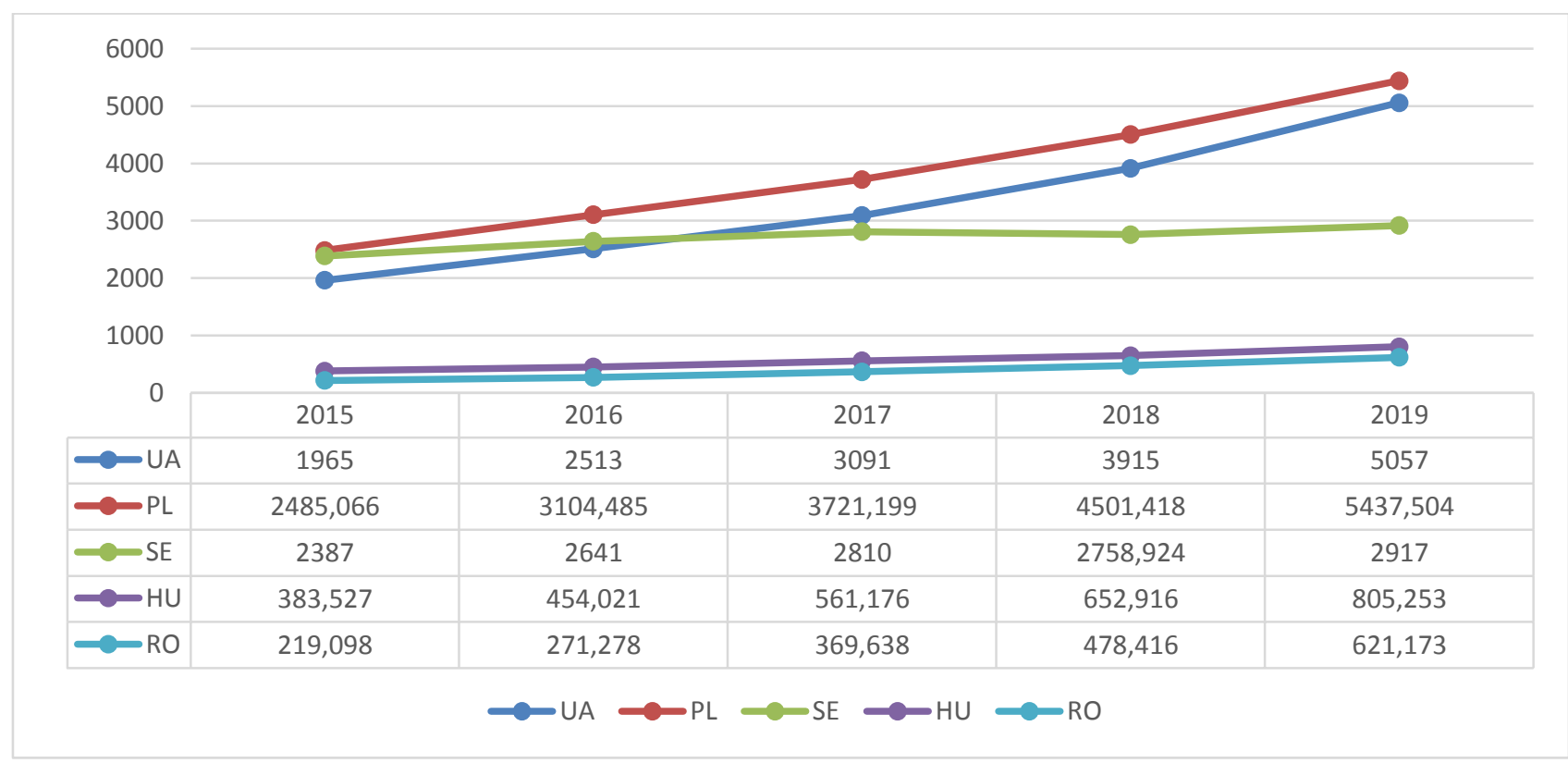

Figure 2. Number of bank card payments in European countries, in million

Source: $N B U, E C B, E B F$ results of data processing.

During the period from 2015 to 2019, the number of transactions using payment cards in the analyzed countries grew every year. Accordingly, the role of cashless payments and payment systems increased during the studied period.

It should be noted that the main factors influencing the number of non-cash payments using payment cards are the population, the number of payment cards and the country's payment infrastructure.

The population of countries is a very important factor, because it is based on the use of noncash payments and payment systems, so further research it will be conducted on the population of Ukraine, Poland, Sweden, Hungary and Romania, their dynamics and relative deviation over the years.

Poland had the largest number of bank card payments in 2019, amounting to 5,057 million transactions. Compared to Poland, the number of non-cash card payments in Ukraine was $7 \%$ less. Such a large number of transactions stems from the significant population of the countries discussed below (Table 2).

Population in European countries, thousand people

\begin{tabular}{ccccccc}
\hline Year & $\mathbf{2 0 1 5}$ & $\mathbf{2 0 1 6}$ & $\mathbf{2 0 1 7}$ & $\mathbf{2 0 1 8}$ & $\mathbf{2 0 1 9}$ & $\begin{array}{c}\text { Relative } \\
\text { deviation 2019 } \\
\text { from 2015 } \\
\text { years, \% }\end{array}$ \\
\hline UA & 42761 & 42585 & 42386 & 42153 & 41902 & -2 \\
PL & 38455 & 38427 & 38422 & 38413 & 38390 & $-0,16$ \\
SE & 9799 & 9923 & 10058 & 10175 & 10279 & 4,89 \\
HU & 9843 & 9814 & 9788 & 9776 & 9771 & $-0,73$ \\
RO & 19822 & 19706 & 19593 & 19477 & 19370 & $-2,28$ \\
\hline
\end{tabular}

Source: ECB, EBF results of data processing. 
Arabadzhy, K., Zharnikova, V. \& Sobolieva-Tereshchenko, O. (2021), “Transformation of cashless payments in the European payment card market”, Management and entrepreneurship: trends of development, 1(15), pp.8-23. Available at: https://doi.org/10.26661/2522-1566/2021-1/15-01

Hungary and Romania had insignificant, compared to other countries, absolute importance of bank card transactions, more than five times less than in Ukraine. Such small figures also follow from the population of these countries.

In 2019, Sweden had 2,917 million non-cash transactions. The country's population is $48 \%$ smaller than in Hungary and 7\% larger than in Romania. That is, taking into account the indicators of the population, with such indicators of the use of cashless payments and it can be said that Sweden is more developed in terms of non-cash payments and payment systems.

At the same time, not only the population affects the number of non-cash payments. The number of payment cards and the country's payment infrastructure have a significant impact. Important indicators are the ratio of the number of cards to the population of the country and the ratio of the number of cards to the number of POS-terminals for payment by cards (Table 3 ).

Table 3

\section{Number of cards, bank card transactions and POS-terminals in European countries}

\begin{tabular}{|cccccccccccccccccccc}
\hline \multicolumn{1}{c}{$\begin{array}{c}\text { Number of cards per 1 } \\
\text { person (number of cards / } \\
\text { population), pcs. for 1 person }\end{array}$} & $\begin{array}{c}\text { Number of bank card transactions per } \\
\text { 1 person (number of bank card } \\
\text { payments / population), pcs. for 1 } \\
\text { person }\end{array}$ & $\begin{array}{c}\text { Number of cards per POS } \\
\text { (number of cards / number of } \\
\text { POS), pcs. for 1 terminal }\end{array}$ \\
\hline Year & UA & PL & SE & HU & RO & UA & PL & SE & HU & RO & UA & PL & SE & HU & RO \\
\hline $\mathbf{2 0 1 5}$ & 0,72 & 0,92 & 2,54 & 0,91 & 0,75 & 45,9 & 64,6 & 243,6 & 38,9 & 11,05 & 177 & 76 & 136 & 80 & 104 \\
$\mathbf{2 0 1 6}$ & 0,76 & 0,96 & 2,15 & 0,91 & 0,81 & 58,6 & 80,7 & 266,1 & 46,26 & 13,8 & 162 & 69 & 83 & 74 & 99 \\
\hline $\mathbf{2 0 1 7}$ & 0,82 & 1,02 & 2,08 & 0,93 & 0,84 & 72,9 & 96,8 & 279,4 & 57,3 & 18,9 & 150 & 63 & 83 & 62 & 85 \\
$\mathbf{2 0 1 8}$ & 0,88 & 1,07 & 1,91 & 0,96 & 0,89 & 92,8 & 117,2 & 271,1 & 66,8 & 24,5 & 132 & 52 & 70 & 60 & 85 \\
\hline $\mathbf{2 0 1 9}$ & 1,01 & 1,12 & 1,82 & 0,96 & 0,94 & 120,6 & 141,6 & 283,8 & 82,4 & 32,06 & 126 & 47 & 74 & 60 & 80 \\
\hline
\end{tabular}

Source: Own study and ECB, EBF results of data processing.

According to ECB, EBF results of data processing (European Central Bank and European Banking Federation, 2019-2020), the ratio of the number of payment cards per capita in the studied countries had a growth dynamic in all but Sweden. In 2019, this figure in Sweden was 18,729 thousand units. by 10,279 thousand population, which is $24.87 \%$ less than in 2015 . But this does not mean that the Swedish banking sector has begun a process of degradation and decline. This trend in Sweden is due to the fact that the country is focused on environmental improvement. The country is gradually abandoning plastic cards and switching to virtual cards in online applications and e-wallets. This factor is also supported by the fact that Sweden uses the latest blockchain technologies and the transition to digital currency to use cryptocurrencies, especially Bitcoin.

In Ukraine, the number of payment cards in 2019 was $41,158,000$, which was $33.46 \%$ more than in 2015. In Poland in 2019, the number of payment cards amounted to 42,854 thousand units, which was $21.71 \%$ more than in 2015 . Romania and Hungary also had an increase the number of payment cards for five years by $21.9 \%$ and $4.92 \%$, respectively. That is, banks issued a larger number of payment cards of various types, which was caused by an increase in demand for non- 
cash payments by cards on the Internet and a relative improvement in the acquiring functions of banks.

In all countries, there is a dynamic increase in the number of POS-terminals in trade during the study period. In Ukraine in 2019, this figure was 333,840 units, and had an increase of $91.53 \%$ compared to 2015. This crazy jump is explained by new legislation, which correlates with the introduction of POS-terminals in trade and the transition from cash to non-cash payments. Ukraine and Poland are somewhat similar in terms of indicators, but in Poland the indicators of the number of cards per 1 person and the number of non-cash transactions are higher. Ukraine has the highest number of cards per POS-terminal in trade, which indicates a significant issue of cards, and more progressive operation of terminals, because during the study period, this figure decreased by $28.8 \%$ in 2019 compared to 2015.

In Poland in 2019 there were 906,564 POS-terminals, which is 572,724 more than in Ukraine for the same period, this is due to a more developed business area in Poland than in Ukraine, but this is helped by a large proportion of Ukrainians who leave home to look for work. That is, Poland, creating many jobs and opportunities for business development, encourages Ukrainian citizens to work, thereby increasing the number of terminals for payment in trade and reducing the population of Ukraine.

Sweden has the largest coverage of acquiring banking services and the number of transactions per person. In this country, the number of POS-terminals in trade in 2019 was 251,975 , which is a very good indicator of their population and increased by $37.28 \%$ compared to 2015, which again indicates a transition to non-cash calculation. In Sweden in 2019, there are 1.82 cards per person, and this is the highest figure among the studied countries. It is noteworthy that this figure is higher despite the fact that Sweden has integration into the use of blockchain technologies and reduced use of plastic cards. That is, when other countries switch to non-cash payments, Sweden is already looking to the future and starting to use digital currency payments. The number of bank card transactions is also much higher than in other countries and amounts to 283.8 transactions per person in 2019.

Hungary in 2019 has an average of all countries, the number of cards per person in 2019 was 0.96, and Romania in 2019 in terms of the number of cards per POS-terminal took second place among the analyzed countries and amounted to 80 pieces. Hungary and Romania also tended to increase the number of bank card transactions per capita by $41.26 \%$ and $58.9 \%$, respectively. The indicators of Romania and Hungary are lower than Ukraine in some respects, but the population of these countries is 2 or 3 times less than Ukraine.

Thus, Sweden can be called a benchmark for Ukraine in the development of non-cash payments using payment cards. In order to improve public services and accelerate the transition to non-cash payments, Ukraine needs to grow up and learn from at least its Polish counterparts. It is established that the number of cards per person in Ukraine as well as in Poland. At the same time, there are more POS-terminals in trade in Poland, which may mean a more developed level of entrepreneurship and business than in Ukraine.

This is evidenced by the existing problems of the Ukrainian state in the field of business, namely:

A tax code that has a constant tendency to change and is almost never been permanent;

- Corrupt mechanisms through which certain individuals do not legally obtain land plots and opportunities to conduct their business;

- High interest rates on loans to small and medium-sized businesses (which until 2018 flowed from the discount rate of the NBU, because before that the monetary policy of the National Bank was tougher;

- Temporary problem - COVID-19 pandemic (currently this factor is a problem in all European countries). 
Arabadzhy, K., Zharnikova, V. \& Sobolieva-Tereshchenko, O. (2021), “Transformation of cashless payments in the European payment card market”, Management and entrepreneurship: trends of development, 1(15), pp.8-23. Available at: https://doi.org/10.26661/2522-1566/2021-1/15-01

An important factor in the development of small and medium-sized businesses in the country, or business in general, is the factor of increasing the number of POS-terminals in trade, which are directly used in calculations of sold products, goods or services other. With the help of payment cards and electronic payments, the world is gradually giving up cash. But different countries have different conditions for this development.

Ukraine has shown quite good results in the use of such banking services related to non-cash payments, acquiring and development of POS-terminals (National Bank of Ukraine, 2020). Noncash transactions are used in large quantities. The total number of transactions (non-cash and cash receipts) using payment cards issued by Ukrainian banks in 2020 increased by $18.0 \%$, and the amount - by $8.7 \%$ compared to the same period in 2019 . This trend is primarily due to the growing amount and quantity of non-cash transactions. Their share predominates in the total amount of payment card transactions. Thus, the amount of non-cash transactions amounted to more than 55\% of the sum of all card transactions. Last year, following the results of 2019, this figure was less than $50 \%$. The number of non-cash transactions is even higher - 86 out of 100 transactions with payment cards were carried out non-cash. Payment infrastructure in Ukraine continued to expand steadily during 2020. The number of businesses accepting payment cards has increased by almost $32 \%$. In addition, since the beginning of 2020, the number of commercial POS-terminals has also increased - by $7.9 \%$. At the same time, more than $85 \%$ of all commercial POS-terminals provide contactless payment.

Of course, this trend correlates not only with the improvement of banks under the leadership of the NBU, but also with changes in legislation in the country. By the way, the POS-terminal can be used for the benefit of the country, in terms of monitoring the correct posting of income by imposing a tax on this income, which then goes to the state treasury. For example, the formation of bank statements and reports of the entrepreneur, using data from POS-terminals, which reflect all the calculations of the population and the receipt of funds in the bank accounts of merchants.

\section{CONCLUSION}

Currently, the whole world is switching to cashless payments, which have been popular for many years. Analyzing the prevalence of the most popular banking transactions related to non-cash payments and payment systems in Ukraine, Sweden, Poland, Romania and Hungary, it has been found that Sweden in this work is a benchmark to be compared to all countries compared.

Sweden's banking system is working at a strong level for the current population. The mentality of Europeans, namely the Swiss, to invest in new technologies is very important. The citizens of Sweden themselves opposed the large issue of payment cards, because, firstly, it is dangerous for the environment, and secondly, the population supported the government in organizing the development of payment for goods and services in digital currency, which is now becoming an important tool as a financial mechanism in some countries with developed economies.

Poland also showed good results in this research. In general, the banking system of Ukraine's neighbor is more developed and open to business processes and ordinary banking operations.

The Ukrainian card market is very dynamic, leaders are changing, new products and technologies are appearing. Only one thing remains unchanged - it is rapidly expanding due to new cardholders, issuers and service points.

This study showed Ukraine's capabilities in the field of typical banking services and allowed to compare the level of development of banking services with other European countries. To improve the situation with serving their customers, banks need:

- Attract foreign attention to domestic investors;

- Take experience from foreign colleagues; 
- Moderately change the interchange rate;

- Open new service technologies (blockchain, cryptocurrency, mobile banks);

- To improve the environmental situation - to produce bank cards from material that does not harm nature;

- For more active use of electronic means of payment it is necessary to ensure further development of infrastructure, as well as to promote the development of financial literacy.

Assume, the implementation of the above recommendations will allow to expand cashless payments using payment cards in Ukraine, and the results of research will be useful for further research in the market of payment cards in European countries.

The results of the research can be used in the development of non-cash payment processes using payment cards, the introduction of new banking services based on the use of cards and the solution of certain business cases in banking.

\section{REFERENCES}

Chaikovskii, Ya. I. and Kovalchuk, Ya. Yu. (2018), "Banking innovation: prospects and threats of e-banking", Svit finansiv, vol. 4. pp. 121-136, (in Ukrainian).

Cronk, J. J. (2015), The digital transformation of financial services is a secure investment in the future. Cisco. Available at: https://www.cisco.com/c/dam/m/ru_ru/internet-of-everythingioe/iac/assets/pdfs/Cisco_Financial_ru.pdf (Accessed 17 January 2021).

European Banking Federation (2020), "Poland`s banking sector: Facts \& Figures". Available at: https://www.ebf.eu/poland/ (Accessed 17 January 2021).

European Banking Federation (2020), "Romania`s banking sector: Facts \& Figures". Available at: https://www.ebf.eu/romania/ (Accessed 17 January 2021).

European Central Bank (2019), "Payment card accepting devices". Available at: https://sdw.ecb.europa.eu/browse.do?node=9691546 (Accessed 17 January 2021).

European Central Bank (2019), "Payment card functions". Available at: https://sdw.ecb.europa.eu/browse.do?node=9691545 (Accessed 17 January 2021).

European Central Bank (2019), "Statistical Data Warehouse". Available at: https://sdw.ecb.europa.eu/browseSelection.do?type=series\&q=total+population\&node=SEAR CHRESULTS\&ec $=\& \mathrm{oc}=\& \mathrm{rc}=\& \mathrm{cv}=\& \mathrm{pb}=\& \mathrm{dc}=\& \mathrm{df}=($ Accessed 17 January 2021).

European Central Bank (2019), “Total population”. Available at: https://sdw.ecb.europa.eu/quickview.do?SERIES_KEY=390.ENA.A.N.PL.W0.S1.S1._Z.POP ._Z._Z._Z.PS._Z.N (Accessed 17 January 2021).

Ferrari, M.M., Arnaud, M. and Livio, S. (2020), "Central bank digital currency in an open economy". ECB Working Paper Series, issue 2488 / November 2020. P. 67. Available at: https://www.ecb.europa.eu/pub/pdf/scpwps/ecb.wp2488 fede33ca65.en.pdf?ac12ca088c7351 3aca6012ea1e3671d2 (accessed 17 January 2021).

Floh, A. and Treiblmaier, H. (2006), "What keeps the e-banking customers loyal? A multi-group analysis of the moderating role of customer characteristics on eloyalty in the finance service industry", Journal of Electronic Commerce Research, 7(2), pp. 97-110.

Kharchenko, V. and Kapralov, R. (2010), "Statystychnyy analiz rynku bankivs'kykh platizhnykh kartok v Ukrayini u konteksti krayin iz rozvynutymy kartkovymy rynkamy”, Visnik $N B U$, vol.5, pp. 44-52, (in Ukrainian).

King, B. (2017), Bank 3.0. Why Banking is No Longer Somewhere You Go, But Somewhere You Do, Singapur: Marshall Cavendish Editions, 400 p.

Kravets, V. (2016), "Rozvitok platizhnikh sistem v Ukraïni ta novitni formi rozrakhunkiv" [Development of payment systems in Ukraine and the latest forms of payments], Visnik NBU, pp. 45-47, (in Ukrainian). 
Arabadzhy, K., Zharnikova, V. \& Sobolieva-Tereshchenko, O. (2021), “Transformation of cashless payments in the European payment card market”, Management and entrepreneurship: trends of development, 1(15), pp.8-23. Available at: https://doi.org/10.26661/2522-1566/2021-1/15-01

Maslennikov, E., Lomachynska, I., and Bychkova, N. (2017), "Ensuring the stability of the Ukrainian banking system in the context of institutional transformation", Scientific bulletin of Polissia, 4 (12), pp. 62-70.

Minfin (2020), "Number of banks in Ukraine (2008 - 2020)". Available at: https://index.minfin.com.ua/banks/stat/count/ (Accessed 17 January 2021).

National Bank of Ukraine (2020), "Transactions made by using payment cards, 2019”. Available at: https://bank.gov.ua/ua/news/all/operatsiyi-zdiysneni-iz-vikoristannyam-platijnih-kartok-2019rik (Accessed 17 January 2021).

National Bank of Ukraine (2020), Financial indicators of Ukraine's financial reporting. Available at: https://bank.gov.ua/en/statistic/supervision-statist/data-supervision (Accessed 17 January 2021).

National Bank of Ukraine. Official web site. Statistical data and various reports. Retrieved January 11, 2021. Available at: https://bank.gov.ua/en/statistic/nbustatistic (Accessed 17 January 2021).

Novak, Í. and Goncharenko, L. (2010), "Sistema termínovikh pokaznikív - noviy yetap rozvitku yelektronnikh bankívs'kikh rozrakhunkív", Visnik NBU, vol. 9, pp. 44-49, (in Ukrainian).

Ramskyi, A., Loiko, V., SobolievaTereshchenko, O. and Zharnikova, V. (2017), "Integration of Ukraine into the European banking system: cleaning, rebooting and Basel III", Journal of Banks and Bank Systems, Vol.12, Issue 4, pp.163-174. Available at: http://dx.doi.org/10.21511/bbs.12(4-1).2017.05.

Reverchuk, S., Vladychyn, U. and Davis, Ch. (2015), "Foreign Banking in Ukraine: Development Trends and Ownership Structure Regulation", Journal of Eastern European and Central Asian Research, 2 (2), pp. 1-14. Available at: https://doi.org/10.15549/jeecar.v2i2.103.

Rushchyshyn, N. and Kostak, Z. (2018), "Bankivs'ka systema Ukrayiny: suchasnyy stan ta perspektyvy rozvytku". Ekonomika $i$ suspil'stvo, vol. 16. pp. 783-789, available at: http://economyandsociety.in.ua/journals/16_ukr/119.pdf (Accessed 17 January 2021), (in Ukrainian)

Selcen, O., Nihat, K., Mesut, O. and Altug, T. (2019), "Digital National Currency: Example of Sweden and e-Krona", Editorial Universitat Politècnica de València. Available at: https://www.researchgate.net/publication/335542970_Digital_National_Currency_Example_o f_Sweden_and_e-Krona (Accessed 17 January 2021).

Sobolieva-Tereshchenko, O. (2018), "The Bank Card Market: A Comparative Analysis of Ukraine and its Neighboring Countries", Comparative Economic Research, 21(4), pp.25-44, available at: https://czasopisma.uni.lodz.pl/CER/article/view/3878 (Accessed 17 January 2021), DOI: https://doi.org/10.2478/cer-2018-0025.

Sobolieva-Tereshchenko, O. and Zhukova, Y. (2020), "Stress testing the banking systems: Approach of Ukraine". Journal of Eastern European and Central Asian Research (JEECAR), 7(2), 205-218, available at: https://doi.org/10.15549/jeecar.v7i2.358.

Statista (2020), "Number of banks in Europe (EU28) as of January 2020, by country". Available at: https://www.statista.com/statistics/940867/number-of-banks-in-europe-by-country/ (Accessed 17 January 2021).

The World Bank (2019), Foreign Banks Among Total Banks (\%) Retrieved from https://datacatalog.worldbank.org/foreignbanks-among-total-banks (Accessed 17 January 2021)/

Zharnikova, V. (2019), "Global trends and modern realities development of retail trade in the digital economy", Efektyvna ekonomika, vol. 5, available at: http://www.economy.nayka.com.ua/?op=1\&z=7075. (Accessed 17 January 2021), DOI: 10.32702/2307-2105-2019.5.151. (in Ukrainian)

Zharnikova, V. (2019), "Modern approaches to the formation of the accounting and analytical basis of the accounting organization of calculations with buyers", Efektyvna ekonomika, vol. 6, 
available at: http://www.economy.nayka.com.ua/?op=1\&z=7145 (Accessed 17 January 2021), DOI:10.32702/2307-2105-2019.6.156. (in Ukrainian)

Zorya, S.P. (2017), "Status and features of the functioning of the electronic payment system of the national bank of Ukraine" Efektyvna ekonomika, vol. 11, pp. 1-9, available at: http://www.economy.nayka.com.ua/?op=1\&z=5876 (Accessed 17 January 2021), (in Ukrainian).

\section{СПИСОК ВИКОРИСТАНИХ ДЖЕРЕЛ}

Cronk J. J. (2015) The digital transformation of financial services is a secure investment in the future. Cisco. URL: https://www.cisco.com/c/dam/m/ru_ru/internet-of-everythingioe/iac/assets/pdfs/Cisco_Financial_ru.pdf

European Banking Federation (2020). "Romania`s banking sector: Facts \& Figures". URL: https://www.ebf.eu/romania/ (дата звернення: 17.01.2021).

European Banking Federation (2020). "Poland's banking sector: Facts \& Figures".URL: https://www.ebf.eu/poland/ (дата звернення: 17.01.2021).

European Central Bank (2019). "Payment card accepting devices". URL: https://sdw.ecb.europa.eu/browse.do?node=9691546 (дата звернення: 17.01.2021).

European Central Bank (2019). "Payment card functions". URL: https://sdw.ecb.europa.eu/browse.do?node=9691545 (дата звернення: 17.01.2021).

European Central Bank (2019). "Statistical Data Warehouse". URL: https://sdw.ecb.europa.eu/browseSelection.do?type=series\&q=total+population\&node=SEAR CHRESULTS $\&$ c $=\& o c=\& r c=\& c v=\& p b=\& d c=\& d f=($ дата звернення: 17.01.2021).

European Central Bank (2019). "Total population". URL: https://sdw.ecb.europa.eu/quickview.do?SERIES_KEY=390.ENA.A.N.PL.W0.S1.S1._Z.POP ._Z._Z._Z.PS._Z.N (дата звернення: 17.01.2021).

Floh, A., and Treiblmaier, H. (2006) What keeps the e-banking customers loyal? A multi-group analysis of the moderating role of customer characteristics on eloyalty in the finance service industry. Journal of Electronic Commerce Research, 7(2) 97-110.

King B. (2017) Bank 3.0. Why Banking is No Longer Somewhere You Go, But Somewhere You Do, Singapur: Marshall Cavendish Editions, 400 p.

Maslennikov E., Lomachynska I., Bychkova N. (2017). Ensuring the stability of the Ukrainian banking system in the context of institutional transformation. Scientific bulletin of Polissia, 4 (12), pp. 62-70.

Massimo M. Ferrari, Arnaud M., Livio S. (2020). "Central bank digital currency in an open economy”. ECB Working Paper Series, issue 2488. November 2020. P. 67. URL: https://www.ecb.europa.eu/pub/pdf/scpwps/ecb.wp2488 fede33ca65.en.pdf?ac12ca088c7351 3aca6012ea1e3671d2

Minfin (2020). "Number of banks in Ukraine (2008-2020)". URL: https://index.minfin.com.ua/banks/stat/count/ (дата звернення: 17.01.2021).

National Bank of Ukraine (2020). "Transactions made by using payment cards, 2019". Available at: https://bank.gov.ua/ua/news/all/operatsiyi-zdiysneni-iz-vikoristannyam-platijnih-kartok-2019rik (дата звернення: 17.01.2021).

National Bank of Ukraine (2020). Financial indicators of Ukraine's financial reporting. URL: https://bank.gov.ua/en/statistic/supervision-statist/data-supervision (дата звернення: 17.01.2021)

National Bank of Ukraine. Official web site. Statistical data and various reports. Retrieved January 11, 2021. URL: https://bank.gov.ua/en/statistic/nbustatistic (дата звернення: 17.01.2021) 
Arabadzhy, K., Zharnikova, V. \& Sobolieva-Tereshchenko, O. (2021), “Transformation of cashless payments in the European payment card market”, Management and entrepreneurship: trends of development, 1(15), pp.8-23. Available at: https://doi.org/10.26661/2522-1566/2021-1/15-01

Ramskyi A., Loiko V., SobolievaTereshchenko O., Zharnikova V., (2017). Integration of Ukraine into the European banking system: cleaning, rebooting and Basel III, Journal of Banks and Bank Systems, 12(4), pp.163-174

Reverchuk, S., Vladychyn, U., Davis, Ch. (2015). Foreign Banking in Ukraine: Development Trends and Ownership Structure Regulation. Journal of Eastern European and Central Asian Research, 2 (2), pp. 1-14

Selcen O., Nihat K., Mesut O., Altug T. (2019). "Digital National Currency: Example of Sweden and e-Krona". Editorial Universitat Politècnica de València. URL: https://www.researchgate.net/publication/335542970_Digital_National_Currency_Example_o f_Sweden_and_e-Krona (дата звернення: 17.01.2021)

Sobolieva-Tereshchenko O., Zhukova Y. (2020). "Stress testing the banking systems: Approach of Ukraine". Journal of Eastern European and Central Asian Research (JEECAR), 7(2), 205218.

Sobolieva-Tereshchenko, O. (2018). The Bank Card Market: A Comparative Analysis of Ukraine and its Neighboring Countries. Comparative Economic Research, 21(4), pp.25-44.

Statista (2020). "Number of banks in Europe (EU28) as of January 2020, by country". URL: https://www.statista.com/statistics/940867/number-of-banks-in-europe-by-country/ (дата звернення: 17.01.2021).

The World Bank (2019), Foreign Banks Among Total Banks (\%) URL: https://datacatalog.worldbank.org/foreignbanks-among-total-banks (дата звернення: 17.01.2021)

Жарнікова В. В. Світові тенденції та сучасні реаліі розвитку роздрібної торгівлі в умовах цифрової економіки. Ефективна економіка. 2019. №5. URL: http://www.economy.nayka.com.ua/?op=1\&z=7075 (дата звернення: 17.01.2021). DOI: 10.32702/2307-2105-2019.5.151

Жарнікова В. В. Сучасні підходи до формування обліково-аналітичної бази організації обліку розрахунків 3 покупцями. Ефективна економіка. 2019. №6. URL: http://www.economy.nayka.com.ua/?op=1\&z=7145 (дата звернення: 17.01.2021). DOI: 10.32702/2307-2105-2019.6.156

Зоря С. П. Стан та особливості функціонування системи електронних платежів Національного банку України [Електронний ресурс] Ефективна економіка. 2017, с.1-9.

Кравець В.М. Розвиток платіжних систем в Україні та новітні форми розрахунків. Вісник НБУ. 2016. С. 45-47.

Новак І., Гончаренко Л. Система термінових показників - новий етап розвитку електронних банківських розрахунків. Вісник НБУ. 2010. № 9. С. 44-49.

Рущишин Н. М., Костак 3. Р Банківська система України: сучасний стан та перспективи розвитку. Економіка та суспільство: Науковий журнал. 2018. Вип. 16. С. 783-789.

Харченко В., Капралов Р. Статистичний аналіз ринку банківських платіжних карток в Україні у контексті країн із розвинутими картковими ринками. Вісник НБУ. 2010. № 5. С. 44-52.

Чайковський Я. І., Ковальчук Я. Ю. Банківські інновації: перспективи та загрози електронних банківських послуг. Світ фінансів. 2018. Вип. 4. С. 121-136. 


\section{ТРАНСФОРМАЦІЯ БЕЗГОТІВКОВИХ ПЛАТЕЖІВ НА РИНКУ ПЛАТІЖНИХ КАРТОК КРАЇН ЄВРОПИ}

\author{
Арабаджи \\ Кирило Вадимович \\ Киїський університет імені \\ Бориса Грінченка, Київ, \\ Украӥна
}

\author{
Жарникова \\ Валерія Владиславівна \\ Київський національний \\ торговельно-економічний \\ університет, Київ, Україна
}

\author{
Соболсва-Терещенко \\ Олена Анатоліївна \\ Київський університет імені \\ Бориса Грінченка, Киї, \\ Україна
}

Метою даного дослідження $є$ вивчення поточного стану i перспектив розвитку безготівкових платежів 3 використанням платіжних карток в Україні, Польщі, Швеції, Румунії та Угорщини. У статті розглядаються фактори трансформації терміну «безготівкові платежі» в термін «платіжна система». Методологія: теоретична та практична база даних ринку банківських карток розглядається як інформаційна база дослідження. В ході дослідження були використані загальнонаукові, теоретичні та емпіричні методи, серед яких: аналіз і узагальнення літератури з теми дослідження, методи спостереження та порівняння, структурні методи, методи узгодження і формалізації, графічне і табличне представлення даних. У статті проаналізовано тенденції розвитку нових видів безготівкових грошей, проведено порівняння розвитку ринку платіжних карток по ряду критеріїв, описані основні напрямки сучасного використання платіжних карток для безготівкових розрахунків в країнах, що аналізуються. В ході порівняльного економічного дослідження були використані статистичні дані Свропейського Центрального Банку (СЦБ), інформація сайтів Національного банку України та Центральних банків країн. Результати дослідження показують, що зміни на ринку банківських платіжних карток істотно впливають на розвиток безготівкових розрахунків в економіці країн. Наукова значимість роботи полягає у систематизації та характеристиці основних чинників трансформації терміну «безготівкові платежі» в термін «платіжна система». Практична значимість одержаних результатів полягає у визначенні шляхів удосконалення українського ринку банківських карток з використанням досвіду країн Європейського Союзу. Заслуговують уваги представлені в статті кращі європейські практики, що використовувались на ринку банківських карток в 2015 - 2019 роках.

Ключові слова: безготівкові розрахунки, банк, платіжні картки, POS-термінал, Україна, Польща, Швеція, Румунія, Угорщина.

\section{ТРАНСФОРМАЦИЯ БЕЗНАЛИЧНЫХ ПЛАТЕЖЕЙ НА РЫНКЕ ПЛАТЕЖНЫХ КАРТ СТРАН ЕВРОПЫ}

\section{Арабаджи \\ Кирилл Вадимович \\ Киевский университет имени \\ Бориса Гринченко, \\ Киев, Украина}

\author{
Жарникова \\ Валерия Вдадислававна \\ Киевский нацииональный \\ торгово-экономический \\ университет, Киев, Украина
}

\author{
Соболева-Терещенко \\ Елена Анатольевна \\ Киевский университет имени \\ Бориса Гринченко, \\ Киев, Украина
}

Целью данного исследования является изучение текущего состояния и перспектив развития безналичных платежей с использованием платежных карт в Украине, Польше, Швеции, Румынии и Венгрии. В статье рассматриваются факторы трансформации термина «безналичные платежи» в термин «платежная система». Методология: теоретическая и практическая база данных рынка банковских карт рассматривается как информационная база исследования. В ходе исследования были использованы общенаучные, теоретические и эмпирические методы, среди которых: анализ и обобщение литературы по теме 
Arabadzhy, K., Zharnikova, V. \& Sobolieva-Tereshchenko, O. (2021), "Transformation of cashless payments in the European payment card market", Management and entrepreneurship: trends of development, 1(15), pp.8-23. Available at: https://doi.org/10.26661/2522-1566/2021-1/15-01

исследования, методы наблюдения и сравнения, структурные методы, методы согласования и формализации, графическое и табличное представление данных. В статье проанализированы тенденции развития новых видов безналичных денег, проведено сравнение развития рынка платежных карт по ряду критериев, описаны основные направления современного использования платежных карт для безналичных расчетов в анализируемых странах. В ходе сравнительного экономического исследования были использованы статистические данные Европейского Центрального Банка (ЕЦБ), информация с сайтов Национального банка Украины и Центральных банков стран. Результаты исследования показывают, что изменения на рынке банковских платежных карт оказывают существенное влияние на развитие безналичных расчетов в экономике стран. Научная значимость работы заключается в определении и характеристике основных факторов трансформации термина «безналичные платежи» в термин «платежная система». Практическая значимость результатов заключается в определении направлений усовершенствования рынка банковских карт Украины с использованием опыта стран Европейского Союза. Также внимания заслуживают представленные в статье лучшие европейские практики, используемые на рынке банковских карт в 2015 - 2019 годах.

Ключевые слова: безналичные расчеты, банк, платежные карты, POS-терминал, Украина, Польша, Швеция, Румыния, Венгрия. 